\title{
Ütopya ve Siyaset: Popper, Fukuyama ve Liberal Sol Yaklaşımların Ütopya Yorumunun Ernst Bloch Üzerinden Eleştirisisi
}

\section{Utopia and Politics: Critiquing the Popper's, Fukuyama's, and Liberal Left's Interpretation of Utopia through Ernst Bloch}

\author{
Barış Aydın ${ }^{1}$ (D)
}

'(Dr.), Antalya, Türkiye

ORCID: B.A. 0000-0002-2629-5228

Sorumlu yazar/Corresponding author: Barış Aydın

Antalya, Türkiye

E-posta/E-mail: barisaydin@gmail.com

Başvuru/Submitted: 12.01.2021 Revizyon Talebi/Revision Requested: 21.03.2021

Son Revizyon/Last Revision Received: 23.04.2021

Kabul/Accepted: 30.04 .2021

Atıf/Citation: Aydin, Baris." Ütopya ve Siyaset: Popper, Fukuyama ve Liberal Sol Yaklaşımların Ütopya Yorumunun Ernst Bloch Üzerinden Eleştirisi." Felsefe Arkivi- Archives of Philosophy, 54 (2021): 81-96

https://doi.org/10.26650/arcp.858597

\section{ÖZET}

Bu çalışma ilkin, ütopyacı düşünceye karşı istikrarlı bir muhalefet yürüten liberal düşüncenin sağ kanadındaki Karl Popper ve Francis Fukuyama gibi kanonik isimlerin yaklaşımlarının, zamanın sosyo-ekonomik gelişmelerinin katkısıyla genel siyaset düşüncesinin ana akımına bürünmesi sürecini ve ütopyaya ilişkin fikirlerini değerlendirecektir. Bir kez müesses nizam haline geldiği vakit menşeindeki ütopyacı niteliklerin hilafına değişimin ancak tedricen olması gerektiğini ve aksini savunan siyasal tavır alışların da yersiz radikalizmle malul siyaset dışı yönelimler olduğunu iddia eden ana akım liberal çizginin savunucuları olarak Popper ve Fukuyama, bu çizgilerini radikal bir antikomünizmle taçlandırmışlardır. Aynı çizgide bu kez liberal düşüncenin sol cenahındaki sol-sosyalist fikri inkişaf döneminin ürünü çaplı toplumsal değişim taleplerini, radikal diye tabir ederek neredeyse affedilmez birer kusur gibi kabul eden kimi sol liberal feminist yaklaşımlar ile yenilginin sözde faturasını bu radikalizme keserek siyasal faaliyetini melankolik bir yazıklanmanın ötesine geçiremeyen birtakım liberal sol tavırların bu süreçteki rolü tartışılacaktır. Sonuç itibarıyla bu çalışma, çoğunlukla itham biçiminde zikredilen ütopyacılık tabirini, bu menfi kullanımın nesnesi olmaktan kurtarmak için alternatif ve daha iyi bir yaşama dair yolların çeşitlenmesinin önemli bir başlangıç noktası olarak bir paye gibi kabullenip sahiplenen Ernst Bloch'un umut mefhumu üzerinden yepyeni bir ontolojik ve epistemolojik inşaya tabi tutarak, ütopyacılığın bir tür iade-i itibarına odaklanacaktır.

Anahtar Kelimeler: Umut Ilkesi, Öngörücü Tasavvur, Sol Melankoli, Tarihin Sonu, Antikomünizm.

\section{ABSTRACT}

This study will first evaluate how the approaches of canonical names Karl Popper and Francis Fukuyama, who were originally consistently opposing utopian thought, have become the mainstream of general political thought with the contribution of socioeconomic developments and their opinions on utopia. Popper and Fukuyama 
were proponents of a mainstream liberal line of thinking claiming that once it becomes the establishment, any change should only be gradual despite the utopian qualities of its origin, and political attitudes arguing otherwise are extra-political orientations crippled by undue radicalism. They have thus crowned their line of thinking with a radical anticommunism. In the same line, the study will discuss the roles of left liberal feminist approaches-which deemed the social change demands brought by the development of left-socialist thought as radical, as if they were unforgivable mistakes-and the roles of certain left liberal attitudes who found a so-called "fault" in this radicalism and did not take their political activity beyond a melancholic regret. Consequently, this study will focus on restoring the reputation of the term "utopianism" used as an allegation in two ways: (1) by accepting it as an important starting point for the diversification of the paths to an alternative and better life; and (2) by approaching it through a brand new ontological and epistemological construction based on Ernst Bloch's concept of hope to absolve it from being an object of negative use.

Keywords: Principle of Hope, Anticipatory Consciousness, Left Melancholy, End of History, Anticommunism

\section{EXTENDED ABSTRACT}

In the political world following the Cold War, the claim that Western liberal values and approaches constitute the primary form of thinking is not only an assertion, but it has almost assumed the identity of a natural scientific law. Because of this now established approach, many attempts with the goal of a full-fledged political social transformation-albeit gradual-have been characterized as naïve at best or as dangerous in the worst case, serving against the interests of the established free world, even if they did not make demands for political change that were perceived as radical as revolution. Therefore, utopia and utopianism have been evaluated as a kind of infantile disorder without any value in the eyes of both right and left political thought, and they have been considered a type of empty signifier as an outdated and out-of-circulation field of thinking.

This text focuses on the historical journey of the ideas of renowned figures such as Karl Popper and Francis Fukuyama, who have taken a determined critical attitude toward utopian approaches and positioned on the right side of liberal thought. It analyzes their ideas as they become the main route of political theory with the influence of the social and economic conditions of the day, and their thoughts on utopia. Meanwhile, it observes some feminist liberal left conceptions operating on the left of liberal thought that considered the desire for radical social revolution; this was essentially the product of the left-socialist awakening that lasted from the 1950s to the late 1970 s as too maximalist and as an unforgivable error, especially in the post-Cold War period. In summary, the basic orientation of this work is to render utopianism, which has been discarded as a kind of dreaminess, as an object of ontological and epistemological recovery and reconstruction in accordance with the Hope Principle of Ernst Bloch, who enthusiastically undertook it as a kind of force hunting embodied by a different imagination of world and life, at a stage in which the idea of utopia is denigrated and discredited.

While the claim that the leftist/socialist movements and approaches when a focus on total rather than gradual change prevailed - especially with the effect of May 68 and Latin American Guerrillaism-was disabled by a utopian adventurism that did not grasp the status quo of the social and was a standard memorization of the right in the past, this jargon has been the dominant 
language in the post-Cold War world and has also become an argument frequently voiced by some sections of the left. The spread of this discourse to leftist/socialist approaches has resulted in the only form of left political action being a non-productive, non-transformative, and nonreflective pseudo-criticality, replacing current mourning with an obsession with a melancholic non-object by giving up the demands of radical change as the justification of the conditions of the day and, supposedly, for tactical reasons. The discrediting of revolutionary, radical demands in the eyes of the left also bears serious parallels with Popper's unfair deeming of utopian thought and Fukuyama's tremendous self-confidence in declaring it completely unnecessary without even accepting a collocutor. At this point, the revolutionary and innovative meaning that Ernst Bloch attributes to utopia, utopian thought, and hope is important as it emphasizes these ideas and approaches as potentially radically transforming and constructing social life in the future in a better, egalitarian, and liberal way.

In this sense, Bloch, who believes that philosophy is or should be the product of the joint praxis of cultural production and criticism, has perceived the philosophical horizon of a utopian socialist ontology that does not yet exist-apart from the enlightened fragments of the possible future possibility - in some metaphysical, mystical, or theological parts of what appeared in the past and the present and in those of which we are not yet conscious. In other words, in Bloch's philosophy, every product of human sociality, beyond categorical distinctions such as rational or irrational, artistic or every day, and the like, has become the subject of thinking as a sociocultural heritage that contains the force of another kind of life. These products, which were especially overlooked and dismissed, have been studied even more carefully.

To sum up, in the post-Cold War era, when the idea of a social revolution extinguished, Bloch, stating that the utopian thought continues to sound as unfinished, unclosed pages in the past, is a sui generis thinker that focuses on the strength of the idea of a massive social revolution against liberal approaches, declaring it the winner. He also clearly demonstrates that this selfstyled victory can be problematized through the notions he constructs with a new ontological, epistemological understanding. As a result, Bloch embraced the utopian thought that Popper, Fukuyama, and some left liberals deemed dangerous, unnecessary, and even irrelevant to the point of the day as an example that social life can be reconsidered with a different understanding of reality and temporality. From the exact point that these names criticize it through, Bloch reintroduced it as a special kind of understanding of the demand for a better world. 


\begin{abstract}
"Ve eğer bu [hakikat] olgulara tekabül etmiyorsa -ve biz Marksistler için olgular bir sürecin şeyleşmiş anlarından başka bir şey değildirbu durumda, yaşlı Hegel'in dediği gibi olgulara geçmiş olsun (um so schlimmer für die Tatsachen)."
\end{abstract}

\title{
Giriş
}

Günümüz siyasal arenasında -bilhassa Soğuk Savaş sonrasında- Batılı liberal değer ve yaklaşım biçimlerinin düşünmenin asli formunu teşkil ettiği iddiası, bir iddia olmanın ötesinde adeta doğa bilimsel bir yasa hüviyetine bürünmüştür. Bu artık yerleşik hale gelmiş yaklaşım biçiminin sonucunda, devrim gibi radikal addedilen siyasal değişim taleplerine bile varamadan, tedricen de olsa teşekküllü bir siyasal toplumsal dönüşüm hedefindeki birçok girişim dahi, müesses özgür dünyanın hilafına hizmet eden, en iyi ihtimalle naif en kötü durumda da tehlikeli sıfatlarıyla nitelendirilir olmuştur. Böylelikle ütopya ve ütopyacılık hem sağ hem de sol siyasal düşünce nezdinde kıymeti harbiyesi olmayan bir tür çocukluk hastalı̆̆ı biçiminde değerlendirilmiş ve modası geçmiş, tedavülden kalkmış bir düşünme sahası olarak bir nevi boş gösteren gibi telakki edilir hale gelmiştir.

Siyasal düşüncenin her iki cenahı açısından da siyasal teorik-pratik faaliyet, artık, uzak erimli kimi radikal hedeflerden ziyade yakın hedefli, neredeyse bugünden yarına tatbik edilecek pragmatist nitelikli, küçük ölçekli değişim taleplerinden müteşekkil, gündelik yaşamın sevk ve idare tekniklerinden ibaret gibi düşünülmektedir. Burada, ütopyacı yaklaşımlara kararlı bir eleştirel tavır takınan liberal düşüncenin sağ yanında konumlanan Karl Popper ve Francis Fukuyama gibi namlı isimlerin fikirlerinin, günün toplumsal ve iktisadi koşullarının da etkisiyle siyasal teorinin temel güzergahı formuna bürünmesinin tarihsel seyrine ve onların ütopya bahsindeki düşünceleri irdelenecektir. Bununla birlikte liberal fikriyatın sol tarafında iş gören, esasen ellilerden yetmişlerin sonuna kadar süren sol-sosyalist uyanışın mahsulü olan radikal sosyal devrim isteğini -özellikle Soğuk Savaş sonrası dönemde- fazla maksimalist addedip affı olmaz hata kabilinden değerlendiren bazı feminist liberal sol anlayışlar ile çöküşün kabahatini toplumsal koşullardan kopuk bir hayalcilikten beslendiklerini düşündükleri radikalliğe yükleyerek politik pratik olarak nostaljik bir hayıflanmayı kafi sayan sol liberal fikirlerin, mezkur sağ liberal anlayışları meşrulaştıran karakterine ve onlarla kimi ortaklıklarına dikkat çekilecektir. Özetle bu çalışmanın temel yönelimi, ütopya fikrinin kötülenerek gözden düşürüldüğü bir evrede, daha çok bir tür hayalcilikle birlikte adı anılan ütopyacılığı, başka türlü bir dünya ve hayat tasavvurunun tecessüm ettiği kuvve avcılığı olarak düşünüp hevesle üstlenerek, 1skartaya çıkartılmış bu mefhumu, Ernst Bloch'un Umut İlkesi uyarınca ontolojik ve epistemolojik anlamda bir yeniden ihya ve inşanın nesnesi kılmaktır.

1 Ernst Bloch ve Michael Löwy, "Olgulara Geçmiş Olsun”, Çev. U. Uraz Aydın, Ernst Bloch’la Söyleşiler içinde, Ed. U. Uraz Aydın (İstanbul: Habitus Yayınları, 2015), 37. 


\section{Popper ve Fukuyama'da Ütopyanın Liberal Yergisi}

Solda ve hatta klasik Marksist metinlerde de sosyalizan yönelimli ütopyalara dönük sarkazma varan çapta acımasız eleştiriler zikredilmiş olsa bile bu eleştirellik ya da eleştirelliğin ötesinde kötüleme, karalama literatürünün bayraktarlığını esas itibariyle liberal tandanslı yazar ve düşünürler yapmıştır. Liberal düşünce bir kez cari liberal kapitalist düzenin ana akımı hüviyetine bürünüp kendi durumunu tahkim ettikten sonra menşeindeki ütopyacı kök ve motivasyonları neredeyse inkâr etmiş ve kendini siyaset ve siyasalın yegâne tanımlayıcısı, hatta doğal mecrası olarak lanse ederek değişimin de ancak tedricen ve usulünce gerçekleşmesi gerektiğini salık veren bir "kademeli reformizmi" benimsemiştir².

Bu minvalde kurulu düzene muhalif sol-sosyalist akım ve hareketler de tavsiye edilen kademeli reform güzergahı açısından -kimisi benzer bir aşamacılığı benimsemiş olsa bile- aralarındaki doz farkına bakılmaksızın neredeyse tümden mutlak öteki, düşman biçiminde telakki edilmiştir. Bu sebeple müesses nizamın amiral gemisi Amerika Birleşik Devletleri özelinde de mezkûr ütopyacılık karşıtlığının bu liberal versiyonu Doğu Bloku'nun çöküşü sonrası nesnesini kaybetmiş görünse bile anti-komünist söylemle de göbekten iltisaklı olmuştur. Bu süreç sonrasında liberal, neoliberal ve neo-muhafazakâr gibi türlü biçimlere bürünen liberal düşünce nezdinde antikomünizm, dozajı giderek azalsa bile kurulu düzene muhalif hareketlere gösterilen tepkiler bakımından adeta bir Prokrustes yata $\breve{g ̆}^{3}$ olarak liberal ütopya karşıtlı̆̆ının dip akıntısı biçiminde iş görmeye devam etmiştir.

İkinci Dünya Savaşı'nın yarattı̆̆ı muazzam tahribatın kökenindeki sosyo-ekonomik nedenleri göz ardı edip mezkur savaşı arızi nitelikli iki ideolojik sapkınlığın çekişmesinden doğan bir talihsizlik gibi hayli yüzeysel bir noktadan değerlendiren dönemin liberal anlayışı, savaşın karşı taraflarında yer almış Nazizm ve Reel Sosyalizmi aynı sepete atarak sanki bir ve aynı şey derekesinde indirgemiş ve bu kanlı kavgayı teşekküllü toplumsal dönüşüm düşüncesi olarak devrim mefhumunun şeytanlaştırmasının vesilesi haline getirmiştir. Müesses nizama dönük şikayetlerin adeta esastan değil usulden tartışılması gerektiğini salık veren bu yaklaşımıyla liberalizm, böylelikle kendini de cari nizamın ortak grameri olarak konumlandırmayı başarmıştır. Sol-sosyalist düşünce de teşekküllü toplumsal değişim fikrinin en mütekamil örneklerinden biri olarak liberal düşünür ve akımlar tarafından en mühim rakip biçiminde değerlendirilmiş ve liberalizmin tehdit algısı ve pozisyonu da bu eksende şekillenmiştir.

Liberal düşüncenin ütopya karşıtlı̆̆ının İkinci Dünya Savaşı sonrasında en yetkin örneklerinden biri olan Karl Popper’in Açık Toplum ve Düşmanları çalışması, dönemin iki kutuplu dünyasında Soğuk Savaşın liberalizmin ideolojik ve kurumsal düzeyde hakimiyetine en ciddi

2 Kathi Weeks, Çalı̧ıma Sorunu, Çev. Tamer Tosun (İstanbul: Ayrıntı Yayınları, 2014), 238.

3 Bir Antik Yunan efsanesine göre Prokrustes namlı bir haydut yoldan geçenleri elinde bulunan biri kısa biri uzun iki yatağa, uzunları uzuvlarını keserek kısaya uygun hale getirip yatırmak kısaları da uzuvlarını çekip uzatarak uzun yatağa yatırmak suretiyle işkence edermiş. Bkz. Colette Estin ve Helene Laporte, Yunan ve Roma Mitolojisi, Çev. Musa Eran (Ankara: TÜBİTAK Popüler Bilim Kitapları, 2002), 11. Bu minvalde Prokrustes yatağı çağlar boyunca dar kafalılığın, taammüden indirgemenin, laf söz dinlemez otokratlığın simgesi olarak anılmaktadır. 


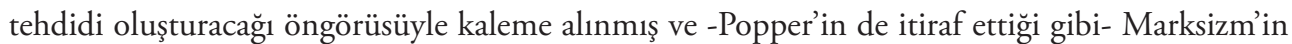
her şeyden daha büyük bir sorun olduğu yönünde çubuğun fazlasıyla büküldüğü bilinçli bir teyakkuzun ürünü olmuştur ${ }^{4}$. Polemik niteliğindeki bu çalışmada Popper'in akıl ve arzu arasında uzlaşmaz bir karşıtlığın olduğu savı üzerine temellendirdiği yaklaşımı, kendinden menkul bir biçimde duygu ve arzulardan arınmış bir akıl nosyonuyla davranan, nesnel ve yansız yargıdan kaynaklanan rasyonel tavrı dolaysızca icraya ehil rasyonel liberal birey ön varsayımından hareket etmektedir.

Popper ayrıca, bu biçimde tanımladığı rasyonel bireyin idealleriyle kişinin ya da kitlelerin salt duygularına seslenen ve oradan alacağı duygusal tepkileri derinleştirip tutkulu bir angajmana dönüştürerek bir tür bağnazca intisabı hedefleyen ütopyacılar arasında da kategorik bir ayrıma gitmektedir. Popper'a göre, rasyonalist tavır kendi varoluşumuz ve onun cüzi iradesine, kısıtlılıklarına yönelik bir farkındalığa kapı aralarken, ütopyacı tavır bu türden meseleler karşısında cüzi çözümlerden ziyade büyük soruların peşinde bir histeriye fazlasıyla meyyaldir ${ }^{5}$. Bir başka açıdan Popper nazarında akıl, insan toplumsallığı ve müşterek ahenk talep ve ufkuyla rabıtalı iken ütopyacı anlayış, tabiatı itibarıyla kaosla ilişkili olduğundan buna uygun düşen akıldışı duygulanımlara yönelerek Hobbesçu anlamda bir şiddetin müsebbibi olmaktadır ${ }^{6}$.

Bugünkünden farklı bir dünya ve toplumsal yaşam arzusundan kaynaklanan teşekküllü bir dönüşüm fikri olarak ütopyacı tavrın ayartıcılığını kendi de teslim eden Popper, bu hevayı da her daim makul, akli tepki ve pratikler içinde olmanın cefası ve sürekli doğruda durma yönündeki müteyakkız halin yorgunluğuna bağlamaktadır ${ }^{7}$ Bu minvalde cari dünyadan başkasına yönelik ütopyacı arzu ve hayaller Popper'in felsefesinde, potansiyel olarak tehlikeli ve yıllardan beri süzülüp gelen teorik-pratik rasyonel mirasın insana kazandırdığı akli muhakeme kabiliyetinde göreli kırılganlıklar yaratarak akamete uğratan kimi olumsuzlukların müsebbibi biçiminde değerlendirilmektedir. Liberalizme muhalif, bilhassa sosyalist/komünist nitelikli siyasal eylem ve değişim girişimlerini ütopyacı mühendislik olarak damgalayıp onun karşısında liberal aşamalı mühendislik modeli öneren Popper, sosyal anlamda en yüce iyinin peşinde, ona meftun ve tüm siyasal eylemini sadece bu çerçevede sevk ve idare eden büyük çaplı devrimler uğruna savaş vermekten ziyade bunun yerine en büyük ve acil kötülükleri tespit edip onların giderilmesi ve teskin edilmesi yönünde cari sistemde küçük ölçekli değişimler lehine mücadele etmeyi salık vermektedir ${ }^{8}$.

Ağır bilançolu iki dünya savaşından muzaffer çıkmış liberal kapitalist düzenin yeni yeni toparlanmaya çalıştığı evrede kaleme aldığı bu çalışmasında Popper, mezkûr rejimlerin felsefi ve siyasal arka planını teşkil ettiğini düşündüğü Marx ve Platon gibi isimler üzerinden, cari liberal kapitalizmin karşısında alternatif mahiyetinde yer almaya gayret eden reel sosyalist rejimleri

4 Weeks, Çalışma Sorunu, 239.

5 Karl R. Popper, Conjectures and Refutations (New York \& London: Basic Books, 1962), 363.

6 Karl R. Popper, Açık Toplum ve Düşmanları Cilt 2 Hegel, Marx ve Sonrası, Çev. Harun Rızatepe (İstanbul: Remzi Kitabevi, 1989), 202.

7 Popper, Conjectures and Refutations, 358.

8 Karl R. Popper, Açık Toplum ve Düşmanları Cilt 1 Platon, Çev. Mete Tunçay (İstanbul: Remzi Kitabevi, 1989$)$ ), 155. 
tehlikeli ve akıldışı bir ütopyacılıkla malul olmakla eleştirmiştir. Dolayısıyla Popper'e göre Hür Dünyanın bundan sonraki selameti açısından izlemesi gereken yegâne iktisadi ve siyasi güzergâh, yine kendine referanslı bir akıl nosyonunu haiz rasyonel siyasal eylemliliğin biricik adresi olan liberalizmden başkası değildir ve cari durumda ona muadil makul bir başka seçenek de yoktur.

Popper'in dönemin şartlarından kaynaklı müteyakkız ruh halinin aksine tarihin artık sonunun geldiği iddiasının ferah feza ileri sürülebileceği, Doğu Bloku’nun çöküşünün eli kulağında olduğu bir tarihsel kesitte bunun özgüveniyle söz alan Fukuyama da liberal demokrasilerin sınırlarının tedricen gelişmesinin ve bu yolla ortaya çıkan ufak değişimlerin toplumsal yaşamın sevk ve idaresi bakımından tek ve en makul yol olduğu konusunda Popper'le mutabıktır. Popper halen yaşamakta olan ve her şeye rağmen bir alternatif güzergâh olarak kitleleri etkileme gücünü haiz bir muarız karşısında mukayeseli bir analiz çabasındayken Fukuyama artık iyice çaptan düşmüş rakibini muhatap dahi kabul etmeden adeta liberal demokrasinin küresel zaferinin düğün alayından konuşur gibidir.

Fukuyama 1989'da yayımlanan Tarihin Sonu mu? başlıklı oldukça ses getiren makalesinde, son yıllarda cereyan eden siyasal gelişmelerin bundan sonraki dünya adına esaslı bir değişimin işareti olarak okunması gerektiğini belirtmiş ve bu hadiselerin basit birer tarihsel sona eriş olmaktan ziyade insanlığın ideolojik dönüşümünün zirvesine varıldığı, toplumsal yaşamın yönetiminin en mütekamil biçimi olarak Batı Liberal Demokrasisinin cihanşümul bir hüviyet kazandığı gerçeklerinden hareketle adeta tarihin sonuna şahitlik edildiğini dile getirmiştir?. Hadisenin basitçe ideolojik bir kamplaşmanın bir tarafının tarih sahnesinden çekilmesinden ibaret olmaktan çok bizatihi bu haliyle Hegelci anlamda bir tarihin sonuna işaret ettiğini iddia eden Fukuyama, Batı'nın bu su götürmez zaferinin ona alternatif olmak amacındaki makul seçeneklerin de büsbütün ortadan kalkmasında temayüz ettiğini savlamıştır ${ }^{10}$.

Buradan hareketle Fukuyama’ya göre cari durumda insanlık, herhangi bir ideolojik-politik düşüncenin kendini müşterek insan yaşamının en doğru, mükemmel ve nihai biçimi gibi sunup bu yönde mücadele yürütmesinin gerekli olmaktan çıktığı bir tarihsel kesite ulaşmıştır ${ }^{11}$. Doğu Bloku ülkelerindeki hükümetlerin, müesses otoriter yönetimler ve planlı ekonomi politikalarından mürekkep çifte krizin sonucu çöküp gitmeleriyle beraber iki binli yılların eşiğinde insanlığın elinde evrensel vasfını haiz ve onu hak eden liberal demokrasi, bireyin özgürlüğü ve halk egemenliğinden müteşekkil bir rejim olarak Batıda mütehakkim olan siyasal rejimlerin kaldığını belirten Fukuyama, bu cari durumu Fransız ve Amerikan Devrimleri esinli özgürlük ve eşitlik ideallerinin sadece dayanıklılı̆̆ olarak değil yeniden yaşam bulma konusundaki maharetine yormak gerektiğini dile getirmiştir ${ }^{12}$.

Bu noktada liberal demokratik kapitalizm bahsinde Fukuyama, bir pozisyonu diğerine karşı savunmaktan ziyade zaten zaferini ilan edip tekelleşmiş bir pozisyonu olduğu haliyle benimsemek

9 Francis Fukuyama, “Tarihin Sonu mu?”, Çev. Yusuf Kaplan, Tarihin Sonu mu? içinde, Der. Mustafa Aydın ve Ertan Özensel (Ankara: Vadi Yayınları, 2002), 22-23.

10 Fukuyama, "Tarihin Sonu mu?", 22.

11 Fukuyama, "Tarihin Sonu mu?", 40.

12 Francis Fukuyama, Tarihin Sonu ve Son İnsan, Çev. Zülfü Dicleli (İstanbul: Profil Yayıncılık, 2011), 76. 
ya da betimlemek ve önceki liberal düşünürlerin savunmacı reflekslerinden farklı olarak tehlike teşkil ettiği düşünülen ütopyacı fikirlere yapılan duygusal yatırımın da sürecin kendi doğallığında etki ve cazibesini kaybederek adeta cari Batı liberalizminde vücut bulduğunu söylemek dışında yeni bir şey yapmamıştır. Bir diğer deyişle eski toprak liberallerin ütopyacı alternatifleri tehlikeli ve olmaması daha iyi olacak olan biçiminde telakki eden müteyakkız yaklaşımlarının karşısında Fukuyama'nın kalem oynattığı tarihsel evredeki neoliberal yaklaşımlar nezdinde bu seçenekler artık tehlikeli bile olamayacak kadar çaptan düşüp lüzumsuzlaşmış ve siyasetin gerçek bir konusu olmaktan çıkmıştır.

Bütün bu tarihin sonu anlatısına karşın bu sürecin sonrasının pek o kadar keyifli olmayabileceğini, kendisinin bile kimi zaman nostaljik bir yazıklanmayla çelişkilerin varlığından beslenen sanat ve felsefenin yokluğuna iç geçirdiğini belirten Fukuyama, kendi gibileri bile hüzünlendiren bu sıkıcı evrenin, kim bilir belki bir gün tekrar tarih kapısının yeniden açılmasıyla son bulabileceğine dair bir ihtiyat payı da bırakmıştır ${ }^{13}$. Popper'in tedirginliği ve Fukuyama’nın timsah gözyaşlarına rağmen Soğuk Savaş sonrasının tek kutuplu dünyasında, Margaret Thatcher gibi simge isimlerin önderliğinde neoliberal söylem, hem cari gerçeklik hem de olası geleceklerden tümünün geçerli dili olarak kendini tahkim etmeyi başarmış, daha doğru bir deyişle bu söylem dünyanın olmakta olduğu halden başka bir biçimde olmasının imkansızlığına iman etmeyi sürekli vaaz eden "yeni bir tür ekonomik kadercilik"14 vasıtasıyla bir nevi artırılmıs gerçeklik hüviyeti kazanmıştır.

\section{Feminizm ve Sol Liberal Melankolinin Ütopyas(1zlığ)1}

Soğuk savaş dönemindeki Popper'in teyakkuzunu haklı çıkaracak çapta palazlanan ve reel sosyalist rejimlerin çöküşünü müteakip Fukuyama tarafından da müstehzi bir edayla rakipsiz ilan edilen neoliberal dilin dönemin adeta lingua franca'sı haline gelmesi, sağdan sola bütün siyasal toplumsal ideoloji ve yaklaşımları da enine keserek hepsini farklı boyut ve çapta olsa bile etkilemiş, sol/sosyalist düşüncenin çeşitli türleri arasında liberalizmin özgürlükçü ve tedricen değişim boyutuna vurgu yapan ve eski karşıtlık dilinden ziyade bu ortak lisanın içinden konuşmayı makul ve geçerli tek yol kabul eden liberal ön takılı kimi yeni güzergahlar uç vermeye başlamıştır. Bilhassa Mayıs 68'in ve Latin Amerika Gerillacılığının etkisiyle tedricen değişimden ziyade topyekûn değişime odaklı bir acilciliğin hüküm sürdüğü dönemin sol/ sosyalist hareket ve yaklaşımlarının toplumsalın olmakta olduğu haliyle kavranmasından uzak ütopyacı bir maceracılıkla malul oldukları savı, önceleri sağın standart bir ezberiyken Soğuk Savaş sonrasının dünyasında hâkim dilin bu jargon olmasıyla beraber solun kimi kesimlerine de sıklıkla dillendirilen bir argüman haline gelmiştir.

Bu minvalde feminizm, zaten eskiden beri mensubu olduğu sol camia içinde bile olası bir devrim sonrasında kolaylıkla halledilebilecek toplumsal cinsiyet eşitliği gibi -aynı zamanda kadınlığın doğal sıfatları olarak sürekli zikredilen tabirlerle müsemma bir biçimde- süfli, naif ve

13 Fukuyama, "Tarihin Sonu mu?”, 49.

14 Pierre Bourdieu, “A Reasoned Utopia and Economic Fatalism”, New Lef Review 227 (1988), 128. 
ütopik hülyalarla fazla meşgul olmakla sıklıkla itham edilmesiyle ilginç bir noktada durmaktadır. Bu minvalde ütopyacı düşünce de toplumsal gerçeklikle gevşek bağları ve meselelere duygulanımsal boyutta yaklaşımıyla kadınsılaştırılmış, feminizm de kimilerince benzer biçimde "bir kuramsal uygulama ve politik müdahale tarzı olarak"15 cinsiyetçi doğallaştırmaların tarihsel niteliğini vurgulamasıyla ütopyacı tavrın kadınsılığının mümeyyiz bir örneği biçiminde telakki edilmiştir. Buradan hareketle feminizm, cari toplumsal cinsiyet rejiminin doğal temelleri haiz olduğu şiarına karşı sorgulayıcı ve ezber bozucu bir tavır takındığı için hızlıca gerçeklikle bağı kopuk olarak yaftalanarak pratik siyaset sahasının marjinal unsurlarından biri gibi konumlandırılmıştır.

Solun güçlü olduğu 70'li yıllar, salt toplumsal cinsiyet eşitliğiyle yetinmeyip aile, heteroseksüel ilişki, aşk, evlilik vb. birçok toplumsal kurumun lağvedilmesi gerektiğini savunan, üretim araçları üzerindeki kontrolün kadınlarca ele geçirilmesi gerektiğini vaaz eden, cari toplumsal cinsiyet rejiminin tümden yıkılması, tersine çevrilmesi ya da devrime tabi tutulmasının icap ettiğini salık veren radikal feminist hareket ve taleplerin muazzam bir çeşitlilik ve yaygınlıkta zikredildiği bir tarihsel dönem olmuştur. Buna rağmen üzerinden henüz yirmi yıl geçmeden rüzgârın neoliberal siyasal dil lehine dönmesiyle bütün handikaplı toplumsal kesimlerinin kazanımları hızla gerilemeye başlamış ve sürekli bir yangın söndürmeyle meşgul olunan savunma döneminde eski radikal talepler tümden tedavülden kalktığı gibi bunların ezkaza dillendirilmesi bile tehlikeli hatta ihanet olarak görülür olmuştur ${ }^{16}$.

Bütün bu gelişmelerin sonucunda toplumsal cinsiyetin cari halini dönüştürme ufku şimdilerde yerini, istenilen boyutta olmasa bile eskiye göre daha çeşitlenmiş bir toplumsal cinsiyet skalasının en azından olduğu haliyle korunması ve eşitlik yönünde küçük çaplı girişimlerle yetinilmesine bırakmıştır. Aileyi lağvetmek şöyle dursun kadınların çalışma hayatına katılımının artmasıyla eşit çalışma haklarına odaklı hayli dar bir çerçeveye sıkışılmış, kapitalizm bir sorunsal olmaktan ziyade menfi etkileri teskin edilmesi gereken bir hafif kusur olarak telakki edilir hale gelmiştir ${ }^{17}$. Bir başka deyişle feminist radikal talepler, değişen sosyo-ekonomik şartların mevcut kazanımlara yoğun saldırısının bertarafı adına bir kenara bırakılmış, artık gündem dahi olmaktan çıkmıştır.

Mayıs 68 sonrasının toplumsal cinsiyet bahsinde radikal talepleri besleyen bakiyesinin 80'ler itibarıyla yerini tarihin, insanın ve metafiziğin ölümünü ilan eden postmodern yaklaşımlara bırakmasıyla feminist düşünce de bu süreçten nasibini almıştır. Postmodernistlerin büyük anlatıların ölümü temelinde sürdürdükleri tartışmayı kimi ana akım feministler, cari toplumsal cinsiyet rejiminin kökleştiği tarih, insan ve metafizik gibi büyük anlatıların çözündürülmesinde kullanışlı bir enstrüman olarak sitayişle sahiplenmiş; fakat bu yönelim de toplumsal yaşamın çözümlenmesi bakımından önemli açılımlar sağlamış olsa bile cari toplumsal pratiklerin devrimci dönüşümünü mümkün kılacak bir siyasal eylemlilik ve faillik sorununu beraberinde getirmiştir. Bir diğer deyişle postmodernizm feministlere, egemen erkek anlatıların yapıçözüme uğratılmasında ve cari düzenin bihakkın tarifinde müthiş bir maharet kazandırmasına karşın

15 Weeks, Çalışma Sorunu, 244.

16 Robin D. G. Kelly, Freedom Dreams: The Black Radical Imaginaton, (Boston: Beacon, 2002), 11.

17 Weeks, Çalışma Sorunu, 247. 
feminist düşüncenin menşeindeki siyaseten radikalliği, kurtuluş ideallerini ve ütopyacı damarı ise hayli tavsatıp sorgulanır hale getirdiği gibi kavramsal özgünlügünü de tartışma konusu olma tehlikesiyle baş başa bırakmıştır ${ }^{18}$.

Bütün bunların yanı sıra aynı dönemde her türden normatif talebi zımni bir totaliterlik talebi olarak telakki eden ve bunların yerine liberalizmin aşamacılığına paralel bir fragmanterliği öneren postyapısalcı düşüncenin yeni sol akımlar üzerindeki etkisi de eski tarz toplumsal devrim nosyonunun giderek gözden düşmesine yol açmıştır. Teşekküllü ve normatif herhangi bir projeyi özcü, temelci, totaliterliğe meyyal, çoğulculuk karşıtı gibi sıfatlarla etiketleyen bu yaklaşım, feminizm ve yeni sol düşüncenin bu minvalde her türlü girişimden imtina edip kendinden menkul ve amorf bir geniş katılımlılık adına sahih bir siyasal iradeden ziyade palyatif tedbirlerle günü geçirmeye dönük etkinliklerin mikro siyaset diye adlandırılması üzerinden işler hale gelmiştir. Bir başka deyişiyle bu yaklaşım sol camiada "her zaman bir hükmeden politik hakikat varsa, en azından köktenci olmayalım; her rejim bir işgalse, en azından işgal gücü olmayalım”"19 gibi suya sabuna dokunmaktan mümkün mertebe imtina etmeye dayalı bir siyaset yapma tarzını cari kılmıştır. Totaliterlik iddiasının bu bol kepçe kullanımının sonucunda "totalitarizm nosyonu da kariyeri boyunca işlevi serbest radikalleri ehlileştirmek olan ve böylece toplumsal bedenin politikideolojik iyi halini korumasını sağlayan ana ideolojik antioksidanlardan biri”" ${ }^{20}$ haline gelmiştir.

Bilhassa akademik nitelikli sol/sosyalist düşüncede Soğuk Savaş sonrasında hasıl olan eski tip bir normatif düşünceye yönelik teyakkuz hali, bugünden farklı bir geleceğin inşasına dönük ütopyacı tahayyüllerin terk edilmesinin yanı sıra o güne kadar elde edilmiş göreli kazanımların muazzam bir saldırı altında olduğu savıyla giderek cari statükoyu korumaya dönük bir muhafazakarlığı da beraberinde getirmiştir. Böylelikle ortaya, müesses nizamın teşekküllü ve köklü bir tenkidini siyasal eylemliliğe tercih eden; nesnel pratiklerin cari hallerine yönelik dikkate değer ve baskın bir seçenek öner(e)meden iş görmeyi kafi sayan; daha da sıkıntı verici bir biçimde potansiyel imkan ve bereketinden ziyade bizzat kendi yoksunluk ve iktidarsılı̆ı̆ına meftun olan; kendini geleceğe dair ümitliyken değil kenarda ve kifayetsizken rahat ve huzurlu belleyen; böylelikle adeta ruh misali canlılar dünyasında gezinerek yitirdiği arzu ve geçmişine melankolik bir saplantıyla takılıp kalan bir sol çıkmıştır ${ }^{21}$.

Nihayet, köklü değişim taleplerinden günün şartlarını bahane edip güya taktik nedenlerle feragat ederek cari yası melankolik bir yok nesneye saplantıyla ikame edip oradan üretici, dönüştürücü ve reflektif olmayan bir sözde eleştirelliği sol siyasal eylemin yegâne formu haline getirmek, ütopyacı düşünceyi Popper'in amiyane biçimde tehlikeli sayması ve Fukuyama’nın da muazzam bir özgüvenle artık bir muhatap bile kabul etmeden onu büsbütün lüzumsuz

18 Seyla Benhabib, "Feminizm ve Postmodernizm: Huzursuz Bir İttifak", Çev. Feride Evren Sezer, Çatışan Feminizmler içinde, Haz. Seyla Benhabib, Judit Butler, Drucilla Cornell ve Nancy Fraser (İstanbul: Metis Yayınları, 2008), 2629.

19 Wendy Brown, Edgework: Critical Essays on Knowledge and Politics (Princeton: Princeton University Press, 2005), 101.

20 Slavoj Zizek, Biri Totalitarizm mi Dedi? Çev. Halil Nalçaoğlu (Ankara: Epos Yayınları, 2006), 7.

21 Wendy Brown, “Sol Melankoliye Direnmek”, Çev. Şeyda Öztürk, Cogito 51 (2007), 273. 
ilan etmesiyle ciddi paralellikler taşımaktadır. Bu minvalde Ernst Bloch'un ütopyaya, ütopyacı düşünceye ve umuda yüklediği devrimci ve yenilikçi anlam, bu fikir ve yaklaşımların toplumsal yaşamın gelecekte daha iyi, eşitlikçi ve özgürlükçü bir mecrada köklü bir biçimde dönüştürülüp inşa edilmesinin imkanını, geçmiş, şimdiki zaman ve gelecek zaman ayrımının ötesinde bir yekpare zaman tasavvuru üzerinden türeten bir yaklaşıma verdiği esinle oldukça dikkate değerdir.

\section{Ernst Bloch'da Ütopya ve Umut}

Ernst Bloch sadece düşünce dünyası açısından değil içinde anıldığı Marksist gelenek bakımından da ütopya, umut, kültür-sanat gibi genellikle bu gelenekte bile devrimci siyasal eylem bakımından yan sorun ve meseleler olarak görülen ve kimi zaman iyice göz ardı edilen mefhumlara, felsefesinde merkezi bir konum atfetmesiyle ayrıksı bir düşünürdür. Belli bir akıldışılığın tezahürü olarak telakki edilen ve yüksek felsefe ile siyaset bakımından da dikkate değer bulunmayarak ıskarta kavramlar diye üzerinde pek durulmayan bu mefhumların, ilerideki iyi toplum ideali bakımından hayli kilit mefhumlar olduğunu düşünen Bloch, aklın düşünüldüğü kadar rasyonel ilkeler üzerinden değil kimi zaman ve hatta sıklıkla arzu eden, hayal kuran bir veçheye de sahip olduğunu belirterek bu dünyaya dair yeni bir şey söylenebilecekse eğer bunun, işte tam da aklın bu melekeleri vasıtasıyla ancak mümkün olacağını dile getirmektedir.

Ütopya karşıtı düşüncenin temel dayanak noktası, salt bir hesaplama ve tasnif melekesi olarak telakki edilip oldukça dar bir çerçevede tarif edilen akıl nosyonu olduğu ve bu nosyon vasıtasıyla ütopya ve geleceğe ilişkin çaplı dönüşüm projeleri de aklın bir parçası olmaktan ziyade onun karanlık, istenmeyen ya da yok farz edilen bir tarafı ya da akıldışı sıfatlarıyla kodlanan tüm bu arzu ve duygular tarafından sevk ve idare edildiği için Popper ve Fukuyama gibi isimler açısından ütopyacı düşünce ve yaklaşımlar, akıl ve izanla izah edilebilir olmanın çok uzağında şeyler olarak düşünülmüştür. Bu noktada Bloch’un itirazı tam da bu hayli dar akıl kavramsallaştırmasına yönelmiş, Marksizm’in birçok farklı biçimine de sirayet eden bu kendinden menkul nesnelciliğin aklın tamamını temsil eder hale gelmesinin yarattığı son derece teknik, soğuk ve sözde analitik akılcı düşüncenin soğuk akıntısı karşısında bu ünlü Alman düşünür, aklın arzu, tahayyül ve umudu da bünyesinde taşıyan bir bütünlük olarak kavranmasına dayanan sıcak akıntıyı ön plana çıkartmıştır.

İnsani bilgiyi sadece ampirik bir doğruluk nesnesi yahut belli hesaplanabilirliklerin doğrusal bir çıktısı olmaktan ziyade eleştirel nitelikleri ve potansiyel muhtevası bakımından da değerlendirmeyi öneren Bloch, bu türden bir epistemolojinin de ancak, aklın birtakım mantıksal varsayımların teyit aracından ya da şeyleri olmakta oldukları şekliyle ele alan bir melekeden daha çok şeylerin sürekli hareket halinde oluşlarını anlık karelerle yakaladığının farkında ve olanın daha da iyi olabileceğine vakıf bir yeti olarak kavranmasıla mümkün olduğu kanaatindedir ${ }^{22}$. Bir diğer deyişle ütopyacı düşünceyi akıl, gerçekçilik ve bunlardan mülhem kimi kategorilerden türetilen ölçütlerle başarısız olarak yaftalayan yaklaşıma karşı aklı sadece olmuş olanın betimi, tasnifi yahut kavranmasına indirgemeyerek onu olmuşun, olanın ve olacak olanın potansiyeller,

22 Ernst Bloch, Umut İlkesi Cilt 1, Çev. Tanıl Bora (İstanbul: İletişim Yayınları, 2007), 25-26. 
arzular ve tahayyüllerle beraber dinamik kavranışının adı olarak düşünen Bloch’a göre ütopya da böylelikle gerçekliğin özel bir türü biçiminde temayüz etmektedir.

Bloch'un aklı, arzu, umut ve tahayyül eden bir meleke biçiminde tanımlarken ortaya attığ henüz mevcut olmayan (not-yet-become), henüz bilincinde olunmayan (not-yet-conscious) ve umut ilkesi (principle of hope) mefhumları, sadece ütopyacı düşüncenin anlaşılması bakımından değil toplumsal yaşamın tüm veçhelerinin kavranmasına dönük hayli yenilikçi bir ontolojik epistemolojik model önermektedir. Popper, Fukuyama gibi isimlerin yanı sıra kimi Marksist yaklaşımların da amentüsünü teşkil eden olmuş olanı gerçekliğin ta kendisi olarak mutlaklaştıran ve onu sadece vakıayla sınırlayan daraltılmış, donmuş gerçeklik anlayışına karşı Bloch, gerçekliği bir oluş sürecinden salt bir olgu olarak soyutlamaktan ziyade onu, bitmemiş geçmiş, şimdi ve en önemlisi mümkün gelecek arasında dallanıp budaklanmış bir süreç olarak kavramak gerektiğini belirtmekte ve öngörücü tasavvurun da mezkur gerçekliğin mütemmim bir cüzü olduğunu savunmaktadır ${ }^{23}$. Bir başka deyişle henüz olmayan diye adlandırdığı bu ontolojiyle Bloch, gerçekliği geçmiş, bugün ve mümkün gelecek arasında salınan ve bunların tümünü kapsayan bir biçimde kavramsallaştırmakta ve gerçek olan her şeyin salt bir tarihe değil aynı zamanda bir ufka da sahip olduğunu vurgulamaktadır. Ayrıca Bloch'a göre gerçek gerçeklik, şimdiki zamanı, bitmemiş geçmiş, bugün ve mümkün gelecek sathında arzu, hayal, korku, endişe ve özlem gibi insani mefhumlarla ilişkili hem soykütüksel hem de etrafıyla rabıtalı biçimde kavrama ve anlama gayesini ifade etmektedir ${ }^{24}$.

Bloch'a göre henüz bilincinde olunmayan da geleceğin ne olduğunun öngörücü bilinci ve yeninin zihinsel doğum yeri ${ }^{25}$ anlamına geldiği gibi -insan bilinci ve ürünleri maddi dünyanın bir parçası olduğu için- insan varlığının henüz bilincinde olunmayan arzuları da dünyanın kendisinin henüz gerçekleşmemiş ütopik içeriğine tekabül etmektedir. Bloch bu ütopik muhtevanın, insandaki henüz bilincinde olunmayana, bütünüyle dünyada henüz zuhur etmemiş, henüz açığa çıkmamış ya da henüz beyan edilmemiş olana ilişkin olduğunu belirtmiş ve bütün bunların henüz zuhur etmemiş kategorisi üzerinden bilhassa tarihte ve dünyada neyin yaklaşmakta olduğuyla etkileşime girdiğini ve karşılık verdiğini ileri sürmüştür ${ }^{26}$ Böylelikle Popper ve Fukuyama'da gerçekliğe aykırı egzotik bir meyve gibi arızileştirilen ütopya düşüncesi Bloch'un bu kavramsallaştırması vasıtasıyla, gündüz düşleri gibi ihmal edilmiş kategorilerde cisimleşerek toplumsal yaşamın dönüştürülmesi bakımından onların anladığı anlamda da gerçeklikten köklenen fakat zaman ve mekanın tamamını kat eden kıymetli bir kaynak hüviyetine bürünmüştür.

Sosyo-kültürel ürünlerve popüler muhayyiledeyalınkat bir egemen sınıfendoktrinizasyonunun ötesinde kuvve halinde bulunan henüz bilincinde olunmayanı ya da umut ilkesi temelli bir nüveyi de gören yaklaşımıyla Bloch, sosyalist düşüncenin sıklıkla görmezden geldiği birtakım mefhumların sosyalist bir ütopyanın cari kılınması adına tedavüle sokulmasını sağlamıştır. Sanat sanat için midir toplum için midir dikotomisine karşı sanatın içindeki kuvveye dikkat kesilerek

23 Bloch, Umut İlkesi Cilt 1, 246-247.

24 Weeks, Çalışma Sorunu, 255.

25 Bloch, Umut İlkesi Cilt 1, 151.

26 Bloch, Umut Ilkesi Cilt 1, 31. 
sanatı ütopyayı maddi kılan materyalist bir umudun mütecessim hali gibi telakki eden Bloch, büyük eseri Umut İlkesìnde de mezkûr hayallerin, gündüz düşlerinin, siyasi ve sosyal ütopyaların, felsefenin, dinin, masalların, mitlerin, mimarlığın ve popüler kültürün adeta ansiklopedik bir soruşturması ve derlemesini yapmıştır. Bir başka deyişle Bloch'ta umut, insanlarda bir kuvve hatta doğal bir eğilim olarak bulunan fakat üzerinde talimle yetkinleştirip öğrenilebilen bir meleke olarak cümle sosyo-kültürel mühimmattan bulup devşirilebilen, soyut halleri olabilse de somut haliyle insanın içgüdüsel yaşama açlığı ve tutkusunun doğal bir bileşeni olarak sadece bir beklenti olmanın ötesinde insan bilincinin temel bir hattı, tüm nesnel gerçekliğin temel bir belirlenimini de teşkil etmektedir ${ }^{27}$.

Bu anlamda Bloch'un sürekli surette insanlık tarihini doğal tarihle mündemiç bir şey olarak kavrayan yaklaşımı, maddi varlıklar insan türü için var kalmaya devam ettiği sürece, kültürel ürünleri, maddi dünyanın kendisinde var olan arzuların somutlaştırılması olarak okumasına imkân tanımış ve böylelikle Bloch, maddenin yapısında, merkezi bir eksiklik etrafında düzenlenen yaratıcı bir çabayla, yaşanan anın karanlı̆̆ı olarak adlandırdığı şey ekseninde sevk ve idare edilen insanoğlunun yaratıcı öznelliği arasındaki belirli bir geçişliliği sürdürülebilir kılmıştır ${ }^{28}$. Öte yandan Ütopyánın Ruhu'ndaki Bloch da yaşanan anın karanlı̆̆ında insanoğlunun varlığına göre bir deneyim teorisi geliştirme gayesiyle salt hafıza, beklenti ve insan yaratıcılığının mahsullerinden müteşekkil bir tevafukla ancak kişinin kendi kendisiyle yüzleşmesinin mümkün olabileceğine vurgu yaparak bunu yapmadığı durumda kişinin, kendini yaşadığı fakat bir tecrübe unsuru haline getiremediği bir deneyim evreninden çıkmaktan aciz olduğunu iddia etmiştir ${ }^{29}$.

Mezkûr kısırdöngüden çıkışın yolları olarak yaratıcı sanat ve gündüz düşlerinin kıymetini müdafaa ederken Bloch, umut ilkesi gibi herhangi bir yerde tesadüfen ortaya çıkan, sanatın ütopik işleviyle eş anlamlı olan ve öznel niteliği de haiz şiirin, aynı zamanda sanatsal ve bilimsel deha, dini öngörülü deha ve şiirsel dehayı da ihtiva etmesi hasebiyle sanatsal aydınlanmanın ebesi hüviyetinde olduğunu savunmaktadır ${ }^{30}$. Bu nedenle, Marksistlerin genellikle reddettiği bir terim olan deha (genius) mefhumu da Marx’ın iddia ettiği gibi doğayla insanlığın, insanlıkla doğanın, özneyle nesnenin hemhal olması ve sınıf bölünmeleriyle yabancılaşmanın sonunu mümkün kılması sebebiyle, hakiki gerçekliğimizin pekiştirilmesi ve yoğunlaştırılması ya da öngörülmüş beklentiler bakımından her daim şiirsel bir karakter arz etmektedir ${ }^{31}$. Dahası Bloch'a göre kimi sanatçılar ve genç Marx gibi birtakım akademisyenler, tutkuyu ve hayal gücünü titiz bir analizle birleştirerek bilinçli bir biçimde, her bir rakip karşısında, sahte bilincin ampirik gerçekliğini yüceltebilmektedir ki böylelikle bu gibi dehalar bize, herkes geliştiği için bireyin de içinde geliştiği sınıfsı bir toplumun gerçek olasılığını barındıran hakiki bilincimizin varlığını göstermektedir ${ }^{32}$.

27 Bloch, Umut Ilkesi Cilt 1, 19-24.

28 Bloch, Umut Illkesi Cilt 1, 242.

29 Ernst Bloch, The Spirit of Utopia, Çev. Anthony A. Nassar (Stanford: Stanford University Press, 2000), 191.

30 Ernst Bloch, The Utopian Function of Art and Literature, Çev. Jack Zipes ve Frank Mecklenburg. (Cambridge: MIT Press, 1988), 160.

31 Bloch, The Spirit of Utopia, 175.

32 Bloch, Umut Illkesi Cilt 1, 161. 
Bu anlamda tarihin amacını, insanların sıklıkla, ama yanlış bir biçimde kendilerini geçmişte bulundukları hayaliyle evlerinde hissettikleri bir dünya yaratmak olarak tarif eden Bloch, bu ütopyacı hülyanın maddi olarak mümkün olmasının yanı sıra yalnızca insan pratiğiyle değil birçok olasılığın maddenin kendisine içkin olarak bulunması sebebiyle de imkân dahilinde olduğunu iddia etmektedir. Bu minvalde Bloch'un ütopya vizyonu, başka romantiklerin aksine modernlik öncesi hayat formları ve sosyal şartlara başvurmadan yahut onlara methiyeler düzmeden, ütopik projesinin temel direkleri olarak gündüz düşleri, öngörücü tasavvur temelli özlemleri ve geçmişin cümle sosyo-kültürel mühimmatında gerçekleşmemiş vaatleri önceleyen tavrında vücut bulan devrimci romantizm ruhundan $\mathrm{da}^{33}$ ciddi izler taşımaktadır. Bununla birlikte, kendi adına felsefenin sonsuz ilerlemesi fikrini geliştirmeye ve her felsefi sistemin öznenin birliği ve nesneyi mutlak bir bende ya da birisinde aramak istediğine dair atfedilen acımasız koşulu göstermeye çalışan ve bunun da esasen estetik olarak entelektüel sezgide, teorik olarak da karenin daireye yaklaşımı gibi ancak sonsuz yaklaşım (infinite approximation) olması durumunda mümkün olduğunu ifade eden Friedrich Hölderlin ${ }^{34}$ gibi önde gelen romantiklerin aksine Bloch'un Marksizm’le aşılanmış ütopyacı yaklaşımı, insanlık tarihinin sonluluğu içinde ütopik bir heimat yaratma ihtimaline açı olmayı temel meşgale haline getirmiştir.

Bloch'un nazarında, hakiki gerçekliğimizin öngörülmüş beklentileri, dehanın yaratımları veya ufku olarak geniş çapta tanınan üretimlerle sınırlı olmadığı gibi mayasında ütopik bir ışıma taşıyan her şeyi $\mathrm{de}^{35}$ bu minvalde değerlendirmek gerekmektedir. Ütopyacı iddiasını Umut İlkesi nde adamakıllı geliştiren ve destekleyen Bloch, bir dizi gerçek ve muhtemel ihtiyacı bir kuvvetsizlikle ilişkili gören gibi kimi dikkate değer olmayan umut biçimlerinin sınırlı ve yanıltıcı olabileceğine dikkat çekse bile ${ }^{36}$, yine de metalaştırılmış düşük kültür ürünleri, serüven tutkusu ve hatta faşizmde dahi sosyalist neviden bir varlık formuna yönelik özlemin eprimiş resimlerinin müşahede edilebileceği kanaatindedir. Henüz gerçekleşmemişin sosyalist ontolojisi olan ütopyacı müştereğin bu boyutunun, devrimci bilinci besleyen ve orada ütopyaya ve geçmişe duyduğumuz en derin özlemin ifası ve dinamik bir süreç biçiminde ulaşılan bir icrasını garanti ettiğini belirten Bloch'a göre, oradan geleceğin keşfine çıkarken, ütopyayı asla son, statik veya mutlak bir koşul biçiminde değil neredeyse tanımı gereği "geçmişin hayalperest ve melankolik bir tefekkürüne dalma[nın]" da ötesinde "geçmişi devrimci bir eylem için, ütopik bir geleceğe yönelik praksis için canlı bir kaynak haline getir[en]" bir süreç olduğu gerçeğinden hareketle tanımlamak ve gün yüzüne çıkarmak gerekmektedir ${ }^{37}$.

Bütün coşkusuna karşın her türlü umut, hikmet, hüsnü kuruntu ya da dünya hakkında, yalnızca düşünmeyle bir şeyin değişmeyeceğini de bilen Bloch, tüm ütopyacı özlem biçimlerinin, gelecekteki olasılıkları reddeden ve ütopyacı düşünceyi azımsayan ütopya karşıtı veya materyalist tutumlardan daha muteber olduğu konusunda ömrünün sonuna kadar oldukça sert ve kararlı

33 Michael Löwy ve Robert Sayre. İsyan ve Melankoli, Çev. Işık Ergüden (İstanbul: Versus Yayınları, 2007), 245.

34 Friedrich Hölderlin, Essays and Letters on Theory, Ed. ve Çev. Thomas Pfau (Albany: SUNY Press, 1988), 160.

35 Bloch, The Spirit of Utopia, 171.

36 Bloch, Umut Illkesi Cilt 1, 406.

37 Löwy ve Sayre, Ísyan ve Melankoli, 257. 
bir tutum içerisinde olmuş ve soyut ile somut ütopya arasında metodolojik ayrıma gitmiştir. Dileğe hiçbir şeyi değiştirme arzusunun eşlik etmediği ya da dileğin, değişmeyen bir dünyadan arda kalmış dilek sahibinin değişen konumundan başka bir şey olmadığı durumda soyut ütopya, belki de piyangodaki büyük ikramiyeyi kazanmak gibi bir hüsnü kuruntudan ibarettir ${ }^{38}$. Somut ütopyanın her daim gerçekten mümkün olan geleceğe doğru bir plan yönelimli olduğunun bilincindeki Bloch'un nazarında bu mefhum her zaman sosyalisttir -ki gerçek bir imkân da sınıf bilincini, kolektif praksisleri ve nihayetinde ne kadar az kan dökülürse o kadar iyi olacak bir miktar şiddeti de içeren bir devrimi gerektirmektedir.

\section{Sonuç}

Toparlamak gerekirse felsefenin kültürel üretim ve eleştirinin müşterek praksisinin ürünü olduğu ya da olması gerektiğine inanan Bloch, gelecekteki muhtemel imkânın aydınlanmış parçaları haricinde henüz var olmayan ütopyacı bir sosyalist ontolojinin felsefi ufkunu da geçmişte ve günümüzde görünen ve henüz bilincinde olunmayanın metafizik, mistik yahut teolojik bir parçası şeklinde ifade etmiştir. Bir diğer deyişle Bloch'un felsefesinde insan toplumsallığının her ürünü, akılcı ya da değil, sanatsal ya da gündelik vb. gibi kategorik ayrımların ötesinde başka türlü bir yaşamın kuvvesini içince barındıran sosyo-kültürel miras olarak tümden düşünmenin konusu haline getirilmiş, bilhassa göz ardı edilen, kenarda bırakılan ürünler daha da dikkatle incelenmiştir.

Toplumsal devrim düşüncesinin iyice çaptan düştüğü Soğuk Savaş sonrası dönemde bu düşüncenin bitmemiş geçmişte kapanmamış sayfalar olarak ses vermeye devam ettiğini belirten Bloch, kendini muzaffer ilan eden liberal yaklaşımlar karşısında çaplı bir toplumsal devrim düşüncesinin kuvvesine odaklanan tavrı ve yeni bir ontolojik epistemolojik anlayışla inşa ettiği mefhumlar aracılığıyla bu kendinden menkul zaferin sorunsallaştırılabilir olduğunu bütün açıklığıyla gösteren yaklaşımıyla özgün bir düşünürdür. Sonuç olarak Popper, Fukuyama ve kimi sol liberallerin tehlikeli, lüzumsuz ve hatta günün konusu olamayacak çapta konu dışı addettiği ütopyacı düşünceyi Bloch, toplumsal yaşamın başka türlü bir gerçeklik ve zamansallık kavrayışıyla yeniden ele alınabileceğinin örneği olarak tam da bu isimlerin eleştirdiği noktadan sahiplenmiş ve onu daha iyi bir dünya talebinin özel bir kavrayış türü olarak yeniden gündeme taşımıştır.

\footnotetext{
Hakem Değerlendirmesi: Dış bağımsız.

Çıkar Çatışması: Yazar ç̧kar çatıșması bildirmemiş,tir.

Finansal Destek: Yazar bu çalışma için finansal destek almadığını beyan etmiştir.

Peer-review: Externally peer-reviewed.

Conflict of Interest: The author has no conflict of interest to declare.

Grant Support: The author declared that this study has received no financial support.
}

38 Ruth Levitas, "Educated Hope: Ernst Bloch on Abstract and Concrete Utopia”, Utopian Studies 1(2) (1990), 14-15. 


\section{Kaynaklar / References}

Benhabib, Seyla. "Feminizm ve Postmodernizm: Huzursuz Bir İttifak”, Çeviren Feride Evren Sezer, Çatışan Feminizmler. Hazırlayan Seyla Benhabib, Judit Butler, Drucilla Cornell ve Nancy Fraser. 25-43. İstanbul: Metis Yayınları, 2008.

Bloch, Ernst. The Utopian Function of Art and Literature. Çeviren Jack Zipes ve Frank Mecklenburg. Cambridge: MIT Press, 1988.

Bloch, Ernst. The Spirit of Utopia. Çeviren Anthony A. Nassar. Stanford: Stanford University Press, 2000.

Bloch, Ernst. Umut İlkesi Cilt 1. Çeviren Tanıl Bora. İstanbul: İletişim Yayınları, 2007.

Bloch, Ernst ve Löwy, Michael. “Olgulara Geçmiş Olsun.” Çeviren U. Uraz Aydın. Ernst Bloch’la Söyleşiler. Editör U. Uraz Aydın. 33-45. İstanbul: Habitus Yayınları, 2015.

Bourdieu, Pierre. “A Reasoned Utopia and Economic Fatalism.” New Lef Review 227 (1998): 125-130.

Brown, Wendy. Edgework: Critical Essays on Knowledge and Politics. Princeton: Princeton University Press, 2005.

Brown, Wendy. “Sol Melankoliye Direnmek.” Çeviren Şeyda Öztürk. Cogito 51 (2007): 267-274.

Estin, Colette ve Helene Laporte. Yunan ve Roma Mitolojisi. Çeviren Musa Eran. Ankara: TÜBİTAK Popüler Bilim Kitapları, 2002.

Fukuyama, Francis. "Tarihin Sonu mu?” Çeviren Yusuf Kaplan. Tarihin Sonu mu? Derleyen Mustafa Aydın ve Ertan Özensel. 22-49. Ankara: Vadi Yayınları, 2002.

Fukuyama, Francis. Tarihin Sonu ve Son İnsan. Çeviren Zülfü Dicleli. İstanbul: Profil Yayıncılık, 2011.

Hölderlin, Friedrich. Essays and Letters on Theory. Editör ve Çeviren Thomas Pfau. Albany: SUNY Press, 1988.

Kelly, Robin D. G. Freedom Dreams: The Black Radical Imaginaton. Boston: Beacon Press, 2002.

Levitas, Ruth. "Educated Hope: Ernst Bloch on Abstract and Concrete Utopia.” Utopian Studies 1(2) (1990): 13-26.

Löwy, Michael ve Robert Sayre. İsyan ve Melankoli. Çeviren Işık Ergüden. İstanbul: Versus Yayınları, 2007.

Marx, Karl. 1844 El Yazmaları. Çeviren Murat Belge. İstanbul: Birikim Yayınları, 2000.

Popper, Karl R. Conjectures and Refutations. New York \& London: Basic Books, 1962.

Popper, Karl R. Açık Toplum ve Düşmanları Cilt 1 Platon. Çeviren Mete Tunçay. İstanbul: Remzi Kitabevi, 1989.

Popper, Karl R. Açık Toplum ve Düşmanları Cilt 2 Hegel, Marx ve Sonrası. Çeviren Harun Rızatepe. İstanbul: Remzi Kitabevi, 1989.

Weeks, Kathi. Çalışma Sorunu. Çeviren Tanju Tosun. İstanbul: Ayrıntı Yayınları, 2014.

Zizek, Slavoj. Biri Totalitarizm mi Dedi? Çeviren Halil Nalçaoğlu. Ankara: Epos Yayınları, 2006. 